\title{
Editorial: Wound Work
}

\author{
FINTAN WALSH
}

A theatre critic, Bergljot, is the central figure in Vigdis Hjorth's novel Will and Testament, originally published in Norwegian in 2016 and in English in 2019. She and her elder brother have been excluded from inheriting two cabins in their parents' will, which favours their younger siblings instead. Grappling with this injustice, Bergljot comes to acknowledge that she was sexually abused as a child by her father, a man who claims to have been once abused himself. It is a trauma so forcefully repressed by the character and denied by most of her family that its slow dawning threatens to scorch their world.

This pressure extended beyond the novel's pages, however, when Hjorth was sensationally accused of thinly veiling her own family story, compelling her sister to write her own version of events as a corrective. Hjorth's mother threatened to sue Bergen's national theatre in 2019 for staging a dramatization of the text, claiming that the production - rather than the novel - violated the family's privacy.

Concerns for performance's public dimension are scattered throughout the text. At one point in the novel, Bergljot ponders over a production of Ibsen's Peer Gynt - Ibsen being the master archaeologist of family secrets - and at another she is captivated by a recording of Marina Abramović's Rhythm O. What grips Bergljot is the ease with which spectators in the Abramović piece advanced as attackers and retreated as viewers, as if the line between perpetrator and observer was effortlessly fluid. The only difference Bergljot discerns is that by the end of the performance spectators project their self-disgust onto Abramović, who is given as saying, 'They could not stand my person because of what they had done to me."

Hjorth's novel is, on one level, about how trauma affects generations of individuals, families and communities - how it tears them apart, pits one against another. But its reception raises questions about the dangers of filtering what some claim are real events through an artistic medium. Performance, as we see in the novel and its adaption, risks being all too real, not only because of actors' capacity to project verisimilitude and inject emotional force, but also for allowing audiences to potentially be both public observers and accomplices.

Articles in this issue are all concerned with theatre and performance's response to different forms of trauma - both personal and cultural - and the ways and means by which the unbearable is exposed, represented, memorialized, processed and aggravated. While trauma etymologically denotes a wound, at least since Freud we have come to primarily see this injury primarily as a psychological event. But performance helps keep trauma's bodily nature centre stage, and the body's role in negotiating the painful past. In the theatre performance and performative actions 
explored in this issue, traumatic claims ask us to reckon with the persistence of suffering, the vagaries of memory, the insufficiencies of language, and the spectres of culpability that overshadow the present, including those who gather to watch and participate.

In 'Stumbling over History: Stolpersteine and the Performance of Memory in Spain's Streets', Alícia Hernàndez-Grande examines the Stolpersteine, or stumbling stones, which memorialize victims of Nazi violence and the Holocaust. While the Stolpersteine appear across Europe, Hernàndez-Grande focuses on those in the Catalan city of Manresa, where the stones recall twenty-eight Spanish Republicans who were interned at the Mauthausen-Gusen concentration camp. HernàndezGrande considers how the stones function as performative memorials that recall the collaboration of the Franco dictatorship with Nazi Germany. Narrated by an audio guide, the stones invite walking observers into an experience of dual witnessing, for the atrocities carried out under the Nazis and the Franco dictatorship.

We continue walking with Emilie Pine, Maeve Casserly and Tom Lane, who lead us around the former Arab Manshiyya district of Tel Aviv, and the site of a former residential institution for children in Dublin. In 'Walks of Experience: Site-Specific Performance Walks, Active Listening and Uncomfortable Witnessing' the authors explore how digital-audio performance can both effectively respond to troubled pasts, and run the risk of promoting dark tourism, privatization and empathic quietism. Finally, the article considers the kinds of creative strategies available to makers and audiences that might cultivate more active witnessing.

A work for young audiences, created by Indigenous artists, is at the centre of Heather M. Fitzsimmons Frey's article. In 'We Are All Treaty People: IndigenousSettler Relations, Story and Young Audiences', Fitzsimmons Frey examines how the titular production skilfully and sensitively engages with Canada's history of Indigenous-settler relations, by pursuing a respectful, Indigenous-led creation process. Despite dealing with a fraught set of historical circumstances which continue to disturb the present, Fitzsimmons Frey maintains that the production drew on dramaturgical and theatrical techniques that offered hope and healing to Indigenous communities.

In 'The World Cup's Double-Headed Eagle: Gestures and Scenarios in the Football Arena', Jared Strange examines the gesture of the double-headed eagle performed by Swiss players of Albanian-Kosovan heritage at their Serbian opponents in the 2018 World Cup in Russia. Strange explains that, as a symbol of Albanian identity, the double-headed eagle was an assertion of ethno-nationalist pride in Kosovan independence from Serbia in 2008, and amounted to mocking a state that is still coming to terms with its diminished role in the region following the dissolution of Yugoslavia. In Strange's analysis, and despite official claims to the contrary, football became a scene for the negotiation of troubled history, its players' gestures recalling ethnic violence and crystallizing unresolved political conflicts.

'An artist wears his work in place of wounds', ${ }^{2}$ wrote Patti Smith, but for Australian comedian Hannah Gadsby, sometimes the work keeps the wound too wide open. In 'The Killjoy Comedian: Hannah Gadsby's Nanette', Sarah Balkin addresses this sense in Gadsby's stand-up show Nanette. While many psychoanalytically inflected theories 
suggest that comedy may signal a defence against or even a processing of trauma, for Gadsby it marks its repetition, especially when homophobic or misogynistic in nature. Gadsby's solution to the dilemma in which she finds herself is to refuse to be funny, to ostensibly abandon comedy altogether, as it leaves her little room for anything other than self-deprecation as a form of traumatic entrenchment. Balkin's concern is less with the painful nature of Gadsby's complaint than with the ways in which her refusal limits her comic possibilities, forcing her to take up the position of feminist killjoy.

In the best-selling The Body Keeps the Score: Mind, Brain and the Body in the Transformation of Trauma, Bessel van der Kolk emphasizes the body's role in experiencing and managing trauma, maintaining that 'physically reexperiencing the past in the present and then reworking it in a safe and supportive "container" can be powerful enough to create new, supplemental memories: simulated experiences of growing up in an attuned, affectionate setting where you are protected from harm'. Here van der Kolk's claims - which lead him to celebrate theatre - echo the pioneering ideas of Pierre Janet, Jean-Martin Charcot and Freud, who impressed the value of re-enactment in processing suffering. This issue likewise reminds us of theatre's value in reckoning with injury - by observing, enacting or tending to it in the present. This is not solely a psychological or emotional task, the articles suggest, but a physical, material enterprise - one that necessitates boldly reworking form, gesture and language, and reimagining and rebuilding our relationships with other people, places and cultures.

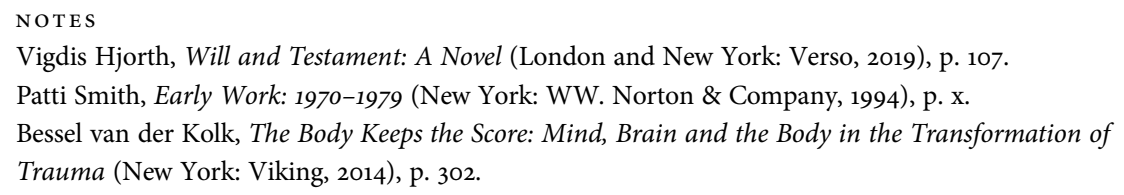

